\title{
What Strives Case Reports in Scientific Field?
}

\section{Dushyant Mital ${ }^{*}$}

Consultant in HIV Medicine, Milton Keynes \& University College Hospitals, UK

Case reports are often viewed as a 'spare part'[1] with evidence based, randomised controlled research trials, audits and subject review articles forming the majority and indeed, the main citation of peerreviewed healthcare and medical journals. Some journals actively discourage the submission of case reports, often mentioning interesting cases in the form of a limited word commentary or letter and even this is viewed as affecting the impact factor of the journal [2]. Interestingly, most healthcare professionals view case reports as having their own role in medical science and education [3]. Case reports have a high sensitivity for detecting novelty and remain one of the cornerstones of medical progress by providing many new ideas in the mechanisms of medicine. Junior healthcare staff often starts 'publishing' careers with case reports and this is often a valuable aid to improve analysis of data and medical writing skills.

This has been spectacularly demonstrated in HIV Medicine when a series of cases of Pneumocystis carinii pneumonia and Kaposi's sarcoma was reported in Los Angeles [4] and San Francisco [5] and subsequently published in 1981. These reports amongst others eventually led to the isolation of HIV in 1983, the detection of HIV antibodies in 1984 and subsequent HIV therapy and related outcomes. This led to a the creation of a new discipline and sub-specialty of medicine which has generated much ongoing research and development leading this to be one of the most studied viruses of our times. One of the strengths of dealing with cases in HIV is that how it links in with other medical and non-medical areas which can often lead to challenging and changing guidelines and protocols. HIV Medicine has links to many other disciplines such as Reproductive Medicine [6], Obstetrics, Paediatrics, Mental Health, General Medicine [7], Surgery, Virology [8], Immunology, Histopathology [9], Dietetics, Dentistry, medicolegal aspects [10] etc and I have been fortunate enough to have been an author of case reports in some of these sub-specialties. In summary, case reports offer the opportunity to improve the practice of medicine in the context of existing knowledge and can enhance the quality of a medical journal.

I thus welcome this new Journal of Clinical Case Reports which emphasises the importance of reporting new and interesting cases in all disciplines. May this long flourish!

\section{References}

1. Stevens $D(2010)$ The context is the 'news' in healthcare improvement reports. Qual Saf Health Care 19: 162-163.

2. Neely JG, Karni RJ, Nussenbaum B, Paniello RC, Fraley PL, et al. (2008) Practical guide to understanding the value of case reports. Otolaryngol Head Neck Surg 138: 261-264.

3. Vandenbroucke JP (2001) In defense of case reports and case series. Annals of Internal Medicine 134: 330-334.

4. CDC (1981) Pneumocystis pneumonia - Los Angeles MMWR 30: 1-3.

5. Durack DT (1981) Opportunistic infections and Kaposi's sarcoma in homosexual men. N Engl J Med 305: 1465-1467.

6. D Mital, JC St John, S Taylor, A Omrani, M Tomlinson, DJ White Can semen quality and mitochondrial DNA be used as a marker of nucleoside toxicity? XIIIth World AIDS conference, Durban, South Africa, Abstract MoPeA2122.

7. D Mital (2006) Kaposi's Sarcoma of the penis. British Medical Journal 332 1400.

8. D Mital, G MacFaul (2011) The ill, jaundiced patient: a triple whammy and the importance of waiting for all results. Clin Med 11: 91-92.

9. D Mital, V Desai (2011) A delayed diagnosis: Conflicting investigation Results should be investigated. Case Reports in Pathology : 2011

10. D Mital, P Roy, D Sheedy, M Raza (2010) Enforcing the law to obtain an HIV test in a minor AIDS - in press.
*Corresponding author: Dr. Dushyant Mital, Consultant in HIV Medicine, Milton Keynes \& University College Hospitals, UK, Tel: 01908826643 x6643; E-mail: Dushyant.Mital@mkhospital.nhs.uk

Received December 05, 2011; Accepted December 08, 2011; Published December 17, 2011

Citation: Mital D (2012) What Strives Case Reports in Scientific Field?. J Clinic Case Reports 2:e106. doi:10.4172/2165-7920.1000e106

Copyright: (C) 2012 Mital D. This is an open-access article distributed under the terms of the Creative Commons Attribution License, which permits unrestricted use, distribution, and reproduction in any medium, provided the original author and source are credited. 